\title{
Kearifan Syariat dan Hikmah dalam Puasa
}

\begin{abstract}
Such a way of thinking was immediately followed by some Muslims especially the ulamas. So that some scholars give special attention by making works that are focused on studying the wisdom, philosophy and wisdom of the Shari'a. like Al Jurjawi with his book Hikmatu Tasyri 'Wafalsafatuhu, Mustafa As Siba'I with his work AhkamuS Shiyam Wa Falsafatuhu, Ad Dahlawy with his work Hujjatullah Al Balighah and other scholars. For this reason, the wisdom and wisdom of Shari'a are very urgent to be revealed in this contemporary era. Through this article the author feels the need to give a little review even though only a small part of the ocean of knowledge and the Shari'a of God which is applied to this people is about the wisdom of the Shari'a and wisdom in the obligation of fasting
\end{abstract}

Keywords: Syara ', Shiyam, Kafarah and Rukhshoh

\begin{abstract}
Abstrak
Cara berpikir demikian segera dsikapi oleh sebagian umat islam terlebih para ulama. Sehingga sebagian ulama memberikan perhatian khusus dengan membuat karya yang memang difokuskan untuk mengkaji hikmah, Falsafah dan kearifan syariat. seperti Al jurjawi dengan kitabnya Hikmatu Tasyri' Wafalsafatuhu, Musthafa As siba'I dengan karyanya AhkamuS Shiyam Wa Falsafatuhu, Ad Dahlawy dengan karyanya Hujjatullah Al Balighah serta para ulama lain. Karena alasan inilah, hikmah dan kearifan syariat menjadi sangat urgen untuk di ungkap di era kontemporer ini. Melalui tulisan ini penulis merasa perlu memberikan sedikit ulasan walau hanya bagian kecil dari samudera ilmu dan syariat allah swt yang diberlakukan bagi umat ini yaitu tentang kearifan syariat dan hikmah dalam kewajiban ibadah puasa.
\end{abstract}

Kata Kunci: Syara', Shiyam, Kafarah dan Rukhshoh

Mufaizin

Dosen PAI STAI Darul Hikmah

Mufaizin@darul-Hikmah.com 


\section{A. Pendahuluan}

Makan, minum dan hubungan biologis merupakan kebutuhan pokok yang harus dipenuhi agar manusia dapat mempertahankan eksistensinya dibumi. Aktifitas dan Pergerakan manusia di dunia dikendalikan oleh dorongan-dorongan yang telah diciptakan tuhan pada diri setiap manusia. Dorongan-dorongan itu berperan penting dalam melestarikan spisies manusia dan memiliki kekuatan untuk memaksa manusia agar mendapat setiap hal yang menjadi kebutuhannya. Terkadang dorongan itu kuat dalam memaksa manusia untuk mendapatkan sesuatu yang menjadi kebutuhannya. Kadang kala juga dapat dikendalikan oleh manusia. Al Ghazali menyebut dorongan itu sebagai syahwat. ${ }^{1}$

Berkat dorongan tersebut, pada tahap selanjutnya, manusia menjadi sosok yang tidak dapat melepaskan diri dari interaksi dengan sesamanya. Sehingga, muncul berbagai golongan dan kelompok manusia. Mereka tergabung dalam bentuk suku, bangsa, dan Negara. Puncak tertinggi dari semua itu adalah terciptanya sebuah tatanan yang melingkupi kelompok besar manusia dengan kebudayaannya dan peradaban yang khas. Ilmu sosial klasik menyebut potensi ini dengan istilah madani bi ath thab'i ( memiliki watak untuk selalu berkumpul dan membangun peradaban). ${ }^{2}$

Untuk mewujudkan tatanan duniawi yang ideal, seperti yang sudah disebutkan diatas, diperlukan paling tidak dua syarat. Pertama, ketertiban urusan publik. Kedua, kualitas individual. ${ }^{3}$ Kualitas individual hanya dapat diwujudkan dengan pembelajaran dan pembiasaan untuk mengendalikan diri bagi setiap individu masyarakat.

Dalam Ilmu Al Quran kontemporer, puasa yang menjadi bagian dari ritual keagamaan yang disebutkan dalam Al Quran, dikategorikan sebagai salah satu mukjizat Al Quran yang tersingkap setelah berkembangnya ilmu pengetahuan modern. Az Zarqani menuturkan bahwa puasa memiliki tiga

\footnotetext{
${ }^{1}$ Al Ghazali. 2005. Ihya 'Ulum Ad Din. Bairut Darul Kutub Al 'Ilmiyyah. Cet, ke-4. Jilid 3. Hlm 8.

${ }^{2}$ Ibnu Khaldun. 2008. Muqaddimah Ibnu Khaldun. Bairut: Darul Kutub Al Islamiyyah. Cet. Ke-8. Hlm. 33.

${ }^{3}$ Al Mawardi. Tt. Adab Ad Dunya wa Ad Din. Surabaya: Al Haramain. Hlm. 158-181.
} 


\section{Kearifan Syariat dan Hikmah Puasa}

dimensi sekaligus. Tiga dimensi utama tersebut adalah sisi kejiwaan (ruhiyyah; religion psychological) yang menajdi kajian inti para pakar keagamaan dan kesufian. Dimensi ini bersifat transenden, privat, dan tidak terkait dengan hubungan sosial

Kedua, dimensi moral ( akhlaqiyyah) yang merupakan lahan garapan spesialis moral. Aspek moral dalam puasa ini dapat dengan mudah kita pahami karena dalam puasa terdapat pendidikan dan pembiasaan kedisplinan, ketaatan, penerimaan secara lahir batin aturan-aturan yang telah ditetapkan, kepatuhan kepada pemimpin, kesbaran, ketahanan, dan perlawanan terhadap kuasa nafsu, penguatan dorongan kepada perbuatan baik, seperti sedekah, dan sebagainya. Dimensi inilah yang menjadikan puasa memiliki nilai sosial.

Terakhir, puasa memiliki dimens kesehatan. Dimensi kesehatan inilah yang sedang ramai diperbincangkan sebagai bentuk kemukjizatan Al Quran yang telah terungkap seiring laju perkembangan ilmu pengetahuan modern. ${ }^{4}$ Pengetahuan modern membuktikan bahwa puasa tidak berbahaya bagi tubuh selama dijalankan sesuai dengan koridor syariat. Bahkan, puasa dapat memperbaiki kualitas fisis, medis, dan biologis seseorang. Dengan tiga dimensi yang dimiliki puasa, tidak berlebihan jika kita katakan puasa sebagai cara yang sehat secara spiritual, medical, sosial, dan penuh dengan dan hikmah ketuhanan untuk mewujudkan kebaikan dunia akhirat ( shalah ad dunya wa al akhirah).

\section{B. Islam dan Puasa}

Puasa merupakan salah satu rukun islam yang menjadi kewajiban bagi setiap umat islam. Puasa Ramadhan baru diperintahkan kepada umat Muhammad saw. Pada bulan Sya'ban dua tahun setelah mereka hijrah ke Madinah. Itu artinya ibadah puasa baru disyariatkan lima belas tahun setelah diproklamasika agama Islam. Yang menjadi pertanyaan, mengapa puasa tidak diwajibkan pada era awal kelahiran Islam?

\footnotetext{
${ }^{4}$ Az Zarqani. 2003. Manahall Al 'Irfan fi 'Ulum Al Quran. Bairut: Darul Kutub Al Ilmiyyah. Cet. Ke-1. Hlm. 491.
} 
Penggemblengan dan penguatan akidah adalah prioritas utama dalam misi dakwah diawal kemunculan Islam. Ini bisa kita buktikan dengan adanya perbedaan karakteristik antara surat-surat Makkiyah dan Madaniyah. ${ }^{5}$

Akidah yang tertancap kuat dapat menjadikan perintah syariat mudah diterima dan dijalankan dengan ketulusan dan ketundukan. Berbeda ceritanya jika umat sudah diperintahkan menjalankan kewajiban syariat, padahal akidahnya masih rapuh. Alih-alih syariat akan dijalankan, yang terjadi justru muncul penolakan terhadap syariat.

Alasan kedua, karena situasi dan kondisi pada saat itu kurang kondusif. Ketika masih berada di Mekah, umat Islam masih disibukan dengan berbagai macam terror, siksaan, dan intimidasi dari kafir Quraisy. Padahal, untuk menjalankan ibadah puasa, dibutuhkan suasana tenang dan aman. Kondisi itu baru dirasakan sahabat setelah mereka berimigrasi ke Madinah.

Istilah puasa sendiri dalam bahasa arab disebutkan dengan As-Shiyam yang memiliki arti sama dengan kata Al-Imsak; yakni menahan dari melakukan sesuatu atau meninggalkannya. Ketika kuda tunggangan enggan berjalan walaupun sudah dihela berkali-kali, maka akan dikatajan ShamatilKhail-Anis-Sairi (kuda menahan jalannya). Ketika angina tidak berhembus maka akan dikatakan Shamat-Rrih-Anil-Hubub (angina menahan hembusannya). ${ }^{6}$ Begitu perbuatan-perbuatan lainnya ketika tertahan berlangsunganya, maka dapat kita gunakan kata As-Shiyam.

Dalam tinjuan medis, puasa adalah kondisi ketika badan tidak mengkonsumsi makanan untuk beberapa saat atau beberapa jam. ${ }^{7}$ Dengan demikian jika tidak makan dengan alasan menjaga kelangsingan badan, maka hal tersebut sudah dapat dikatagorikan menjalankan puasa dalam

Az Zarqani. 2003. Manahil Al 'Irfan Fi 'Ulum Al Quran. Beirut: Darul Al Kutub Al 'Ilmiah. Cet. Ke-1. Juz 1. Hlm. 113-114.

${ }^{6}$ As-shabuny, 2004. Rawai'ul Bayan Fi Tafsiri Ayatil Ahkam, Beirut. Darul-kutub al-ilmiyah. Hlm491.

${ }^{7}$ Hasan Hammam. "Terapi dengan Ibadah". Terjemahan oleh tim Aqwan Solo dari At Tadawi bi Al Istigfar bi Ash Shadaqah bi Adu'a bi Al Quran bi As Shalah bi As Shaum. 2008. Solo: Aqwam Media Profetika.Hlm. 363 


\section{Kearifan Syariat dan Hikmah Puasa}

tinjauan medis. Tidak makan makanan tertentu karena ada tuntutan medis seperti tidak mengkonsumsi telur untuk menghindari gatal dan tidak makan sebelum menjalankan operasi juga dapat digolongkan puasa dalam terminology medis.

Sedang dalam tinjauan Syara', Puasa memiliki arti menahan dari keseluruhan sesuatu yang membatalakan puasa (makan, minum, bersenggama) mulai dari terbitnya fajar sampai terbenamnya matahari dengan niat dan syarat-syarat tertentu. ${ }^{8}$

Puasa Syar'i dilakukan atas dasar dorongan pengabdian atau ibadah kepada allah SWT. Tidak dilatari oleh keinginan mendapat kedigdayaan, kesehatan sebagaimana uraian di atas, atau hal-hal lain yang diluar ibadah. Dari paparan yang telah penulis sebutkan, kita sedikit banyak mengetahui macamnya puasa, ada puasa berbicara sebagaimana yang di ungkapkan oleh siti Maryam, puasa medis sebagaimana uraian di atas dan adapula puasa syar'i. dengan memperhatikan arti puasa menurut terminology syara' atau fiqih, kita akan bisa membedakan mana puasa yang bernilai ibadah dan yang bukan, sehingga dalam memahami puasa yang dimaksud oleh penulis dalam kajian ini tidak mengalami kesulitan.

\section{Sejarah Puasa dalam berbagai macam tradisi}

Dalam sejarah umat manusia, puasa sudah dikenal sejak zaman kuno, baik untuk terapi pengoqbatan maupun ritual keagamaan tertentu. Dalam dunia pengobatan klasik, puasa dipakai diantaranyaoleh para dokter Alexandria, Mesir, pada masa pemerintahan Batlimus. Seorang dokter yunani kuno, Hippocrates (5 SM). Sudah menyusun cara-cara puasa untuk terapi pengobatan.

Pada abad ke-6 SM, seorang tabib dari cina bernama Shu Jhu Chi yang hidup di Tibet menulis satu bab khusus dalam buku kedokterannya tentang terapi puasa dan terapi makanan. Epicurus, seorang filosof besar

\footnotetext{
${ }^{8}$ Sulaiman Rasyid, 2013. Fiqh Islam, Sinar Baru Algensindo Bandung, hlm 220
} 
sebelum memasuki ujian akhir di Universitas Alexandria, berpuasa selama 40 hari untuk menambah kekuata pikiran dan daya kreatifitas. ${ }^{9}$

Ovivo Corna menggunakan terapi puasa untuk mengobati berbagai jenis penyakit. Sebelumnya, ia mencoba pada dirinya sendiri dan berhasil sembuh dari penyakit kronis yang dideritanya. Ia berumur hamper 100 tahun lamanya. Di penghujung hayat, ia mengarang sebuah buku tentang pentingnya puasa dalam mengobati beberapa penyakit. Buku itu ia beri judul "siapa yang sedikit makan, akan berumur panjang."10

Dalam dunia keagamaan, puasa merupakan ritual yang kuno dan sudah banyak dikenal. Dalam masyarakat yang sudah memiliki peradaban maju, seperti mesir dan bangsa Phoenisia, ${ }^{11}$ puasa sudah dikenal. Mereka berpuasa untuk menghormati Izis. $^{12}$ Mereka juga berpuasa sebelum melakukan ritual pengorbanan. Hal ini bertujuan untuk mensucikan orangorangyang menyaksikan perayaan tersebut. ${ }^{13}$ Penganut Hindu, Brahma, dan Budha di India dan dunia Timur, melaksanakan puasa sesuai aturan yang tertera dalam kitab suci mereka. ${ }^{14}$

Ath Thabari menulis, bahwa umat nasrani pada masa lalu sudah diwajibkan berpuasa pada bulan Ramadhan. Mereka diharuskan tidak makan semenjak bangun tidur dan tidak bersetubuh sama sekali selama satu bulan penuh ${ }^{15}$ Pada umumnya, bulan puasa jatuh pada panas yang sangat terik atau musim dingin yang menusuk tulang. Sehingga, ibadah ini

${ }^{9}$ Ibid. Hlm. 385-386

${ }^{10}$ Hasan Hammam. Op.Cit..Hlm. 363-368.

${ }^{11}$ Phoenisia adalah bangsa yang besar yang pernah hidup di Lebanon sekitar abad ke-26 SM. Mereka menyebar hingga pantai barat. Mendirikan banyak kota, seperti: Beirut, Shoida, Juibal, Arwad, dan lainnya. Mereka juga sudah

bekerja sama dengan kerjaan fir'aun dimasa mesir kuno. Pada akhirnya, wilayah mereka wilayah mereka menjadi rebutanantara dua imperium besar, yaitu Romawi dan Persia. Corak keagamaan mereka mirip dengan keagamaan dengan bangsa Sumeria yang cenderung pada paham naturalis. Tuhan terpenting mereka adalah pasangan dewa Asytarut, dan Hadad. Lihat Louis Ma'luf. 2003. Al Munjid fi Al Lughah wa Al A 'lam. Beirut: Darul Masyiq. Cet. Ke-27. Hlm. 428.

${ }^{12}$ Izis adalah dewi bangsa Mesir yang berkuasa dalam bahasa perjodohan. Saudari sekaligus istri dari dewa Oziris. Memiliki anak bernama Hures. Pernah membangkitkan suaminya dari kematian. Lihat Louis Ma'luf. Op Cit. Hlm. 93.

${ }^{13}$ Al Jurjawi. 1997. Hikmah At Tasyri wa Falsafatuhu. Beirut: Darul Fikr. Cet. Ke-4. Hlm. 152-153.

${ }^{14}$ Hasan Hammam. Op.Cit.Hlm. 364.

${ }^{15}$ Ath Thabari. 2001. Jami' Al Bayan fi Ta'wil Al Quran. Kairo: Dar Hajr. Cet. Ke-1. Jilid 3. Hlm. 154. 


\section{Kearifan Syariat dan Hikmah Puasa}

mengganggu aktivitas perekonomian mereka. ${ }^{16}$ Hal ini mendorong para cendikiawan Nasrani untuk bersepakat memindah waktu puasa pada musim semi untuk memudahkan ritual puasa ini bagi umatnya. Mereka menambahkan sepuluh hari, sebagai kafarah atas perbuatan mereka. Sehingga, hari wajib puasa bagi umat Nasrani adalah 40 hari. $^{17}$

Dalam versi lain, disebutkan bahwa mereka menambahkan dua puluh hari sebagai kafarah sehingga puasa yang wajib dikerjakan umat Nasrani menjadi lima puluh hari sebagaimana di ungkap oleh banyak mufassir klasik ketika menjelaskan maksud kata-kata “orang-orang sebalum kamu," dalam kalimat "Hai orang-orang yang beriman, diwajibkan atas kamu berpuasa sebagaimana diwajibkan atas orang-orang sebelum kamu agar kamu bertakwa” (Q.S. Al Baqarah: 183).

Masyarakat jahiliyah Arab juga sudah mengenal ibadah ini, sebagaimana diriwayatkan Al Bukhari dari 'Aisyah bahwa kaum jahiliyah sudah menjalankan tradisi berpuasa setiap hari 'Asyura (10 Muharram). Rasulullah kemudian memerintahkan umat Islam saat itu untuk menjalankannya. Ini terus berlangsung hingga diwajibkannya puasa di bulan Ramadhan pada tahun keduan hijriyah. ${ }^{18}$

Berpuasa setiap hari ke sepuluh bulan Muharram juga menjadi ritual dalam agama Yahudi. Mereka bahkan mengagungkan dan menjadikannya sebagai hari raya. Mereka berkeyakinan hari itu memiliki nilai historis. Hari itu diselamatkannya Nabi Musa a.s. bersama bani Israil dari kejaran Fir'aun dan bala tentaranya. Sehingga, sebagai ungkapan rasa syukur, Nabi Nuh, dan Nabi Musa melakukan puasa setiap tanggal tersebut. ${ }^{19}$

Dalam keyakinan Yahudi, meramaikan dan merayakan puasa adalah wajib. Umat inilah yang pertama kali membuat perayaan dalam berpuasa

${ }^{16}$ Ats Tsa'labi. Al Kassyaf wa Al Bayan. CD Al Maktabah Asy Syamilah Al Ishdar Ats Tsani. Jilid 1. Hlm.327.

${ }^{17}$ Ibid

${ }^{18}$ Ath Thabari. Op Cit. Jilid 3. Hlm. 154.

${ }^{19}$ Al Midani. 1987. Ash shiyam wa Ramadhan fi As Sunnah wa Al Quran. Damaskus: Darul Qalam. Cet. Ke-1. Hlm. 40. 


\section{Mufaizin}

sebelum umat-umat lain. Mereka meniup $B u q^{20}$ (alat music sejenis terompet untuk perayaan) untuk menandai berakhirnya puasa dan datangnya hari raya. Dalam tradisi Yahudi, puasa juga dilakukan untuk seseorang tertimpa musibah. Setelah menunaikan nazar, mereka juga akan berpuasa untuk menyempurnakan nazar mereka. ${ }^{21}$

\section{Kearifan Ramadhan Sebagai bulan untuk berpuasa}

Dalam tradisi bangsa Arab, terdapat kebiasaan ketika menamai sebuah bulan. Mereka senantiasa mengaitkannya dengan fenomena atau momentum tertentu. Seperti, penamaan bulan Syawwal, diambil dari akar kata Syuula (syaul) yang memiliki arti mengangkat. Karena dibulan ini, pada umumnya unta-unta Arab yang memasuki masa-masa kawin. Dimana setiap akli menjelang perkawinan, unta memiliki kebiasaan mengangkat ekornya. Fenomena inilah yang yang mendorong orang Arab menyebut bulan ini dengan nama Syawwal (yang banyak mengangkatnya).

Sedang, Ramadhan bersal dari kata Ar-Ramdlu_Ar-Ramdla' (sangat panas). Nama ini diambil orang Arab karena pada saat itu nama untuk bulan ini, cuaca berada pada puncak panas ${ }^{22}$ Kemudian apa rahasia dipilihnya bulan yang panas ini sebagai bulan untuk menjalankan ritual puasa? Adakah keistimewaan didalamnya? Apa keistimewaan itu? Untuk menjawab itu, maka, harus ada penentuan pada bulan mana puasa wajib harus dikerjakan. Karena, bila setiap orang diperbolehkan memilih bulan yang ia kehendaki, maka masing-masing biasa saja beralasan akan berpuasa pada bulan depan.

Untuk menghindari hal tersebut dan agar persatuan umat Islam dapat terwujud dalam kondisidan situasi yang kondusif, yakni situasi dimana setiap orang yang berpuasa dapat saling membantu saudara yang lain ( dengan tidak mengganggu puasanya), maka harus ada satu bulan tertentu yang ditetapkan. Lalu bulan apakah itu?

\footnotetext{
${ }^{20}$ Lihat Ibnu Manzhur. Tt. Lisan Al Arab. Kairo: Darul Ma'arif. Jilid 5. Hlm. 389.

${ }^{21}$ Al Jurjawi. Op Cit. Hlm. 153.

${ }^{22}$ Sulaiman Al Jamal. Tt. Hasyiyah Al Jamal. Beirut: Darul Fikr. Jilid 2. Hlm. 303.
} 


\section{Kearifan Syariat dan Hikmah Puasa}

Muhammad Ar Razi ketika menafsirkan ayat Ramadhan (Q.S Al Baqarah: 185) menyebutkan bahwa alasan tersebut adalah sebagai alasan ('illat) dipilihnya bulan Ramadhansebagai bulan puasa. Karena, Allah memberikan keistimewaanpada bulan tersebutdengan menurunkan tanda ketuhanan yang paling agung (ayat rububiyah), yakni Al Quran. Maka, manusia sebagai hamba Allah sangat pantas untuk mengabdikan diri dengan mengerjakan ibadahyang menjadi symbol penghambaannya (ayat al ubudiyyah), yakni puasa. Namun, mengapa yang dipilih sebagai simbol penghambaan adalah puasa, bukan shalat?

Ar Razi, mengemukakan alasan dengan menggunakan argumentasi sufistik. Yakni, untuk memutus egoism manusia (al 'alaiq al basyariyah). Agar setiap manusia dapat mencapai kesadaraan akan eksistensi Dzat dan mendapat pancaran nur dan mukasyafah (tersingkapnnya tabir ketuhanan), dibutuhkan ritual yang ampuh dan dapat menyingkap hijab-hijab yang menjadi penghalang.ritual yang ampuh itua dalah puasa. Puasa adalah sebab yang paling kuat (aqwa al asbab) untuk menghilangkan egoism manusia. Ini dibuktikan dengan kenyataan bahwa arbab al mukasyafat (orang-orang yang memiliki keistimewaan batin) mampu menembus hijabhijab hanya dengan media puasa. ${ }^{23}$

Di atas, sudah kita salah satu hikmah puasaadalh meraih predikat orang yang bertaqwa dan bersyukur. Semua itu dapat tercapai bila pelaksanaan puasa ditempatkan pada waktu yang tepat, yakni pada siang hari. Karena pada saat itu, umumnya manusia sedang menjalankan aktivitas. Yang tentunya bila tidak dilandasi iman yang kuat, niscaya puasa akan berat dilakukan. Beratnya menjalankan ibadah, yang dalam bahasa syariah lazim disebut Ibtila' (ujian), adlah esensi dari pengabdian seorang hambaitu sendiri. Bukankah tidak layak memberikan ujian, tetapi tidak sedikitpun mendapat kesulitan-kesulitan? Maka, bukankah Tuhan benarbenar logis dalam memberikan ujian?

${ }^{23}$ Fakhruddin Muhammad Ar Razi. Tt. Mafatih Al Ghalib. Beirut: Darul Fikr. Jilid 5. Hlm.91. 


\section{Mufaizin}

Dalam tinjuan medis, pelaksaan puasa di siang hari bersamaan dengan padatnya aktivitas justru merupakan cara terbaik untuk membantu mempercepat proses pelarutan. Yakni, sebuah proses penghancuran jaringan-jaringan protein yang terkandung dalam daging dan urat.

Sebagai mana diketahui, dalam hati, otot, dan jantung, bahkan dalam setiap sel manusia yang tergabung dalam lemak, tersimpan dalam zat yang berbentuk glukosa (zat gula). Ketika tubuh tidak mendapat pasokan makanan, maka zat-zat gula dalam tubuh akan diproses menjadi tenaga oleh jantung. Dari sini, terjawab sudah pertanyaan mengapa manusia dapat bertahan hidup selama 40 hari tanpa makan dan hanya membutuhkan air saja. ${ }^{24}$ Dan mengapa aktivitas diet -yang memiliki dengan puasa karena sama-sama menghentikan konsumsi- dapat menurunkan berat badan.

Sedang kegiatan berlangsung bersamaan dengan penghentian makanan ini sebenarnya justru membantu proses pelarutan. Di situ, terdapat penghancuran simpanan energiyang terdapat pada lemakdan glikogen pada siang hari berpuasa. Sedang rasa malas dan lesu serta banyak tidur pada saat berpuasa pada saat berpuasa menyebabkan efekyang berlawanan pada tubuh, di antaranya, ketidak stabilan jam aktivitas tubuh, bertambahnya unsur-unsur berbahaya, dan minimnya proses pencernaan. Dengan demikian, jelaslah puasa yang dijalankan mulai dari terbitnya fajar hingga terbenamnya matahari adalah waktu yang sangat istimewa bagi tubuh. ${ }^{25}$

\section{E. Kearifan Dispensasi Syari'ah}

Dalam ketentuan puasa tidak semua orang diwajibkan melakukan puasa, namun ada beberapa orang ketika dalam kondisi tertentu mendapatkan dispensasi untuk tidak menjalankan ibadah puasa, diantaranya ialah wanita hamil. dan menyusui. Tinjauan medis menyebutkan bahwa jika perempuan hamil membutuhkan asupan makanan yang lebih dibandingkan dengan perempuan yang tidak hamil. Hal ini karena adanya janin yang senantiasa berkembang dan akan terganggu perkembangannya

\footnotetext{
${ }^{24}$ Manusia dapat bertahan hidup tanpa makan selama 40 hari, tiga hari tanpa air, dan tiga menit tanpa udara.

${ }^{25}$ Hasan Hammam, Op Cit. Hlm. 372-373
} 


\section{Kearifan Syariat dan Hikmah Puasa}

jika ada keterlambatan asupan makanan., dari sini pula kita dapat memahami mengapa ibu menyusui juga diperbolehkan tidak puasa, yaitu karena puasa akan mengurang produksi ASI. Terlebih jika cuaca dalam kondisi panas, anak akan menderita karena kurangnya asupan air susu. ${ }^{26}$ Atas dasar inilah mereka kemudian mendapatkan dispensasi dari allah untuk tidak berpuasa.

Selain untuk wanita hamil dan menyusui, dispensasi puasa juga diberikan kepada wanita menstruasi yang umumnya setiap wanita akan mengalami gangguan kesehatan sebelum mengalaminya. Diantara ganggunan kesehatan yang sering timbul adalah pusing, asam lambung yang berlebih, batuk, perubahan kadar denyut jantung, dan pengerutan. Selain itu ada juga ganggunan seperti munculnya perasaan berat, lemah dan pegal-pegal. Keadaan semacam ini sangat menganggu aktivitas serta memberatkan si wanita, dan biasanya gejala-gejala tersebut muncul satu atau dua hari sebelum mengalami mentrsuasi dengan kadar yang berbeda antara satu orang dengan yang lain.

Hal demikian pula yang terjadi pada wanita nifas. Kondisi ketika dan pasca melahirkan yang menguras tenaga, belum lagi merawat dan menyusui anak, tentu hal ini begitu berat bagi para wanita yang dalam kondisi tersebut. Selain untuk menjaga kesehatan bayi juga untuk ibu agar dapat merawat sibuah hatinya dengan maksimal dan baik.

Tuhan yang maha arif dan maha tahu, telah memberikan keringan bagi perempuan yang dalam kondisi haid dan nifas agar ia tidak kehilangan manfaat besar puasa, maka ia diwajibkan mengqada' atauu menunaikannnya dilain hari. ${ }^{27}$

Selain itu, di antara mereka yang berhak mendapat dispensasi syariah adalah para musafir, yakni orang yang melakukan perjalanan

${ }^{26}$ Yusuf al hajj ahmad. 2003. Mausu'ah Al I'jaz Al I'lm Fil Qur'anil Karim Was Sunnah Al Muthaharah.Damaskus. maktabah ibnu hajar.hlm 957.

${ }^{27}$ Mahmud Nazhim An nasimi. Tt. As Shiyam Baina Tthib Wal Islam. Masyurat Lajnah Ilmiyah Linniqabah Atthibba halb. Hlm 28q-29. 
yangbmelebihi jarak dioerbolehkannya mengqashar shalat. ${ }^{28}$ Bila seorang melakukan perjalan kurang dari jarak tersebut, maka ia belum layak mendapat dispensasi tersebut.

Hukum boleh tersebut karena adanya Musyaqqah dalam menjalankan puasa diperjalanan. Karena kesulitan yang dialamai satu orang dengan yang lain tidak sama, maka dibutuhkan standar untuk menentukan kesulitan perjalanan yang dapat memeprbolehkan tidak berpuasa. Yakni sesuai dengan standar yang telah ditetapkan oleh para ulama ialah dengan melihat umumnya perjalan yang diduga dapat menimbulkan kesulitan. Perjalan yang dimaksud adalah perjalan yang mencapai jarak $80 \mathrm{~km}$. catatan lain yang harus di ingat oleh orang yang melakukan perjalanan adalah perjalanan tersebut tidak untuk maksiat, sebab dispensasi syariat (Rukhshoh) tidak dilegalkan bagi pelaku maksiat. ${ }^{29}$

Selain tiga orang dalam kondisi di atas dispensasi syariat juga diberikan kepada orang yang sakit, dengan ketentuan sakit yang dialaminya adalah sakit yang parah. ${ }^{30}$ Hal ini mengecualikan sakit yang ringan dan tidak menggangu puasa.

\section{F. Hikmah dalam Ibadah Puasa \\ 1. Persfektif religius}

Ketika menjalankan puasa, kita dituntut untuk menahan sesuatu yang menjadi kebutuhan sensual nafsu. Selama sehari penuh, kita dilatih untuk mengndalikan keinginan makan dan minum agar kita terlatih untuk menjauhi dan menghindari godaan nafsu untuk memiliki dan mengkonsumsi makanan dan minuman yang diperoleh dengan praktikpraktik yang tidak halal. Seperti hasil korupsi, mencuri, merampas, dan sebagainya. Hubungn seksual untuk sementara waktu juga dikendalikan agar manusia terlatih mengendalikan nafsu libido sehingga terhindar dari zina, onani, dan perselingkuhan. Dengan berhasil menahan diri dari makanan dan kebutuhan seksual semata-mata karena taat kepada Allah

\footnotetext{
${ }^{28}$ Zakariya Anshori, Tt.Ghayatul Wushul. Surabaya. Al aharamain. Hlm 123

${ }^{29}$ Taqiyuddin Al hishny. 2005. Kifayatul Akhyar. Beirut. Darul Kutub Ilmiyah. Hlm 296.

${ }^{30}$ Ibid
} 


\section{Kearifan Syariat dan Hikmah Puasa}

swt., diharapkan kita akan lebih mampu untuk menahan diridari perbuatan yang diharamkan dengan didasari ketaatan kepada-Nya.

Dengan berpuasa, seseorang mempertegas komitmentnya untuk memprioritaskan perintah Allah swt. Dan mengalahkan kesenangan nafsu. Inilah hikmah paling subtansialdari puasa yang ditandaskan Al Quran, yaitu mencetak generasi umat yang bertaqwa.

Puasa juga bertujuan untuk menumbuhkanperasaan senantiasa diawasi oleh Allah swt. Ketika kita sendirian di tempat sepi merasakan lapar dan dahaga, kita memiliki kesempatan makan dan minum dengan tanpa sepengetahuan orang lain. Namun, kita bersikeras untuk tidak melakukannya. Keyakinan masih ada Dzat yang memantau semua perilaku kita, mampu menumbuhkan komitmen moral untuk menyempurnakan ibadah kita selama sebulan penuh. Andaikan semua orang mempertahankan semua sikap seperti ini secara berkesinambungan hingga di selain bulan Ramadhan, akan tercipta sebuah tatanan sosialyang selama ini dicitacitakan.

Dalam bermasyarakat, Rasulullah menggambarkan setiap anggota harus menjaga keselamatan orang lain dengan cara menahan diri dari berbuat kejahatan. Ibarat seseorang yang menaiki perahu ditengah samudra, setiap penumpang harus menahan diri dari melakukan hal-hal yang dapat membahayakan keselamatan bersama. Ketika ada orang yang melakukan kejahatan dengan cara melubangi kapal, maka benar jika yang dikatakan salah adalah si pelaku saja. Namun, bukankah yang menjadi korban adalah seluruh penumpang kapal? Begitu pula dalam hidup bermasyarakat. Bukan yang menerima dampaknya seluruh elemen masyarakat. Bukankah yang jelek adalah masyarakat disekitar pelaku? Maka, menjadi kewajiban setiap individu masyarakat, menjaga diri, dan orang lain dari perbuatan jahat ditengah kehidupan bermasyarakat. ${ }^{31}$

Puasa juga melatih agar senantiasa bersyukur atas nikmat yang telah diberikan oleh Allah swt. Seseorang baru menyadari betapa besarnya nilai

${ }^{31}$ Musthafa As Siba'i. Ahkamus Shiyam Wa Falsafatuhu. Beirut Al-Maktabul-Islami Hlm. 54. 
sesuatu pada saat dia kehilangan. ${ }^{32}$ Dengan tidak merasakan makan dan minum selama berpuasa, kita akan menyadari betapa besarnya karunia Allah selama ini. Kita senantiasa diberi kesehatan dan kelapangan rizki sehingga dapat merasakan nikmatnya makanan dan minuman.

Dalam menjalankan puasa, seseorang tidak dapat dinilai secara lahirnya saja. Orang yang tampak lesu di siang hari bulan Ramadhan belum tentu kalau dia benar-benar berpuasa. Orang yang tampak segar bugar juga tidak bisa kita tuduh sebagai orang yang tidak berpuasa. Ketika dalam keadaan sendiri, seseorang memiliki kesempatan melakukan pelanggaran dengan cara makan atau minum dengan sepengetahuan orang lain. Maka, puasa dalam hal ini sudah menjadi satu hal yang dipercayakan (baca: diamanahkan) kepada seorang hamba. Jadi, dengan puasa, berarti seseorang telah membiasakan diri bersikap amanah dalam hidupnya. Dan hendaknya hal ini didasari oleh setiap pelaku puasa. ${ }^{33}$

Diakui bersama bahwa manusia tidak hanya tersusun dari darah dan daging, sehungga tujuan hidupnya hanya sekedar memenuhi tuntutan keduanya. Dalam diri manusia, terdapat hakikat lain selain kedua unsur materi diatas. Unsur lain itu bersifat abstrak, nonmateri, dan mulia. Unsur lain tersebut adalah sifat-sifat khas malaikat, ruh, dan hati yang tidak dimiliki mahluk lain di muka bumi. ${ }^{34}$

Ketika manusia melupakan unsur esensial ini, maka ia hanya akan menjadi makhluk yang tidak bernilai dan tidak lebih dari hewan-hewan melata lainnya. Unsur hewani adalah rendah dan hina, sedan unsur ruhiyyah malakiyah adalah mulia. Maka, sudah sepantasnya unsur yang mulia dimuliakan dan unsur yang hina direndahkan dan ditindas oleh unsur yang mulia. Karena bila unsur hina menjadi dominan, maka yang ada hanyalah sosok hewan, bukan manusia yang dapat mengatur dan

\footnotetext{
${ }^{32}$ Izzuddin bin Abdissalam. Tt. Maqashid As Shaum. Beirut: Darul Kutub Ilmiyah. Cet. Ke-1. Hlm. 17.

${ }^{33}$ Al Ghazali. Op Cit. Jilid 1. Hlm. 332.

${ }^{34}$ Musthafa As Siba'i. Op. cit. Hlm. 43.
} 


\section{Kearifan Syariat dan Hikmah Puasa}

memakmurkan dunia. Padahal sudah menjadi titah Allah, menjadikan manusia sebagai khalifah yang mengatur dunia.

Jadi dengan puasa, seseorang berusaha membatasi unsur hewaninya (makan, minum, dan seks) dan secara bersamaan memantapkan kekuatan ruhaniyahnya. Atau dengan kata lain, melatih kesabaran dalam puasa sudah sangat jelas. Dalam sehari penuh, seseorang dilatih mengendalikan kesabarandengan cara menahan makan, minum, dan sebagainya. Itu semua dijalankan secara suka rela tanpa ada paksaan. Tentu saja, dalam hal ini terdapat latihan kesabaran tingkat tinggi. Namun,yang perlu dicatat, kesabaran yang dimaksud bukan hanya ketika sedang menjalankan puasa, melainkan senantiasa dijaga konsistensinya meskipun pada waktu-waktu tidak puasa. Pembiasaan ini sangat baik, untuk menekan angka kemaksiatan dalam masyarakat.

Puasa menjawab pertanyaan mendasar tentang penyimpanganpenyimpangan perintah tuhan. Mengapa seseorang mencuri, membunuh, atau berselingkuh? Semua didasarkan pada masalah kesabaran pribadi masing-masing. Seseorang mencuri karena tidak tahan atas apa yang menimpanya dalam masalah ekonomi. Seseorang membunuh, karena ia tidak tahan untuk menghadapi masalah emosi yang menghampirinya. Seseorang berbuat zina tentu karena ia tidak mampu bersabar mengendalikan libidonya. Maka bulan Ramadhan adalah bulan pembelajran terhadap masing-masing individuuntuk bersabar dalam mengendalikan diri. $^{35}$

\section{Persfektif Medis}

Ada sebagian orang beranggapan bahwa puasa mendatangkan banyak sekali efek negatif bagi tubuh. Rutinitas makan sehari tiga kali dipercaya sebagai anjuran medis agar tubuh senantiasa sehat. Sehingga, perubahan pola makan dan perut dalam keadaan kosong selama sehari penuh bisa menimbulkan berbagai macam penyakit dan merusak sistem pencernaan. Anggapan tersebut ternyata sama sekali tidak argumentasi ilmiah. Puasa

${ }^{35}$ Ibid. 
ditinjau dari aspek kesehatan ternyata justru memiliki beberapa manfaat yang mengagumkan. Diantaranya adalah mengistirahatkan organ pencernaan

Pada umumnya, seseorang memiliki kebiasaan makan tiga kali dalam sehari. Dengan kebiasaan ini, secara tidak sadar, dia telah memaksa organ pencernaannya untuk bekerja terus menerus tanpa memberi kesempatan istirahat. Setiap makanan yang masuk akan ditampung dan dicerna sekarang kurang lebih empat jam di dalam lambung. Selama itu pula, makanan dicerna dan dipersiapkan pada kondisi keasaman tertentu dan mengamankannya dari infeksi-infeksi serta diteruskan sedikit demi sedikit menuju keusus halus sampai ke lambung dalam keadaan kosong. Di usus halus, makanan disempurnakan pencernaannya selama kurang lebih empat jam. Jadi setelah menikmati makanan, alat-alat pencernaan terus bekerja dan bisa beristirahat setelah kurang lebih delapan jam. ${ }^{36}$

Dengan melaksanakan makan pagi pada jam 07.00, organ pencernaan baru berhenti bekerja delapan jem berikutnya, yakni pada pukul 15.00 seandainya makan siang dilakukan pada pukul 14.00, sistem pencernaan sudah disuruh lagi memproses makanan yang baru masuk sampai pukul 22.00, padahal pekerjaan yang pertama belum selesai. Belum selesai aktivitas kerja sistem pencernaan memproses makan siang, dia akan dipaksa bekerja lagi jika makan malam dilakukan pukul 20.00, dan baru berakhir pada jam 04.00 pagi. Kita bisa membayangkan betapa sistem pencernaan bekerja keras sepanjang tahun, hamper tanpa istirahat. Dengan berpuasa selama sebulan pada bulan Ramadhan, minimal ada enam jam waktu istirahat bagi organ pencenaan dalam sehari.

Memang benar kuantitas asupan makanan yang masuk selama berpuasa mengalami penurunan. Namun, hal ini tidak berdampak menurunnya gizi yang diserap oleh tubuh. Justru sebaliknya, gizi yang diserap oleh tubuh kualitasnya lebih baik disebabkan organ pencernaan

\footnotetext{
${ }^{36}$ Ahmad Syarifuddin. 2003. Puasa Menuju sehat Fisik dan Psikis. Jakarta: Gema Insasi Press. Cet. Ke-1. Hlm. 108.
} 


\section{Kearifan Syariat dan Hikmah Puasa}

tidak dibebani dengan tugas yang berat sehingga memungkinkan untuk memproses dan menyerap gizi dengan optimal. ${ }^{37}$

Hikmah yang lain sebagaimana menurut Makvadon, seorang ahli kesehatan Amerika, menulis bahwa setiap orang butuh puasa meskipun ia tidak sakit karena racun-racun dalam makanan dan obat-obat kimia yang berkumpul dalam badan akan menjadikan seseorang seperti orang yang sakit. Semangatnya menurun dan tubuhnya terasa berat. Ketika berpuasa ia akan merasa mimiliki bobot tubuh yang ringan. Racun-racun (toxin) akan terurai setelah berkumpul, lalu akan hilang dari tubuh. Akhirnya, tubuh menjadi bersih dari racun-racun tersebut. ${ }^{38}$

Selian menghilangkan racun dalam tubuh, hikmah puasa juga meningkatkan kekebalan tubuh. Hal ini dapat dibuktikan dengan hasil penelitian di Osaka Jepang tahun 1930, yang mana setelah memasuki hari ke-7 berpuasa, jumlah sel darah putih dalam darah orang yang berpuasa meningkat. Pada minggu pertama (hari ke-1 sampai hari ke-6) berpuasa, tidak ditemukan pertumbuhan sel darah putih. Namun, pada hari ke-7 sampai hari ke-10, penambahan jumlah sel darah putihnya pesat sekali. Penambahan jumlah sel darah putih ini secara otomatis meningkatkan kekebalan tubuh sel-sel darah putih ini berfungsi melawan peradangan yang ada dalam tubuh sehingga banyak penyakit radang yang bisa ditumbuhkan dengan bqerpuasa. Misalnya, radang tenggorokan, radang hidung, radang amandel, radang lambung, radang usus, dan radang persendian. ${ }^{39}$

Tanpa kita sadari, di dalam tubuh manusia ternyata terdapat parasitparasit yang menumpang hidup, termasuk menumpang makan dan minum. Dengan menghentikan suplai makanan, kuman-kuman penyakit, bakteribakteri, dan sel kanker tidak akan bisa bertahan hidup. Mereka akan keluar melalui cairan tubuh bersama sel-sel yang mati dan toksin. ${ }^{40}$

\footnotetext{
${ }^{37}$ Ibid. Hlm. 112.

${ }^{38}$ Lihat Muhammad Ibrahim Salim. Tt. At Tadawi bi Ash Shiyam wa Mazayuhu Al 'Azhimah fi Al Wiqayah wa Ash Shiyanah Ash Shihhiyyah wa Al Mu'alajah Al Jismiyyah wa An Nafsiyyah. Kairo: Maktabah Ibnu Sina. Hlm. 99.

${ }^{39}$ Ahmad Syarifuddin. Op. cit. Hlm.116.

${ }^{40}$ Ibid. Hlm. 117.
} 


\section{Mufaizin}

Puasa ternyata juga bisa sebagai terapi penyembuhan penyakit, yang mana Jerman, Dr. Otto Buchinger dan kawan-kawannnya telah menyembuhkan banyak pasien dengan terapi puasa. Setelah pasien dirawat secara medis selama sekitar 24 minggu dan berdisiplin puasa, ternyata mereka lebih segar kembali baik secara fisik maupun mental. Mereka juga lebih bergairah hidup. Menurut terapi diklinik ini, berbagai penyakit, seperti ginjal, kanker, hipertensi, depresi, diabetes, maag, dan insomnia, dapat disembuhkan melalui puasa.

Demikian juga yang terjadi di Moskow Institute of Psychiatry. Menurut Dr. Yuli Nekolar, setelah mengadakan riset dia menyatakan bahwa upaya penyembuhan secara medis yang disertai dengan puasa hasilnya akan lebih baikdan lebih cepat. Hal ini juga telah dibuktikan oleh para pasien yang menjalankan terapi puasa di klinik Health Spa di Amerika.

Puasa bisa bermanfaat untuk menurunkan kadar gula dalam darah hingga mencapai kadar seimbang. Pada saat berpuasa kelenjar pancreas memiliki kesempatan untuk istirahat. Metode pengobatan diabetes dengan sistem puasa selama lebih dari 10 jam dan kurang dari 20 telah dipraktikkan di seluruh dunia. Metode semacam ini telah mencapai hasil yang menakjubkan tanpa menggunakan obat-obatan kimiawi satu pun. ${ }^{41}$

Dalam sebuah hadis disebutkan bahwa Rasulullah SAW menjadikan puasa sebagai solusi alternatif bagi mereka yang hasrat libidonya meluapluap, namun belum siap untuk melangsungkan pernikahan. Solusi yang ditawarkan Rasulullah saw. Lima belas abad silam ini, saat ini berhasil dibuktikan keakuratannya oleh para ilmuan.

Sebuah penelitian tentang pengaruh hormone seks bagi para laki-laki pernah dilakukan disebuah rumah sakit di Amerika. Penelitian ini terdapat 6 orang yang berusia sekitar 26 dan 45 tahun melalui tiga tahap selama delapan belas hari. Tahap pertama, mereka makan seperti biasa selama tiga hari. Tahap kedua, dengan berpuasa sepuluh hari, tidak makan dan minum

${ }^{41}$ Diantara hikmah puasa. http://promote5.blogspirit.com/archive/_2006/04/04 diantara hikmah puasa.html diakses pada tanggal 15 Mei 2018 


\section{Kearifan Syariat dan Hikmah Puasa}

siang malam, kecuali air putih yang boleh dikonsumsi siang dan malam. Tahap ketiga, mereka diberi makan lagi seperti sedia kala selama lima hari.

Hasil tes darah yang dilakukan menunjukkan bahwa hormone seks laki-laki (testosterone) mengalami penurunan dengan frekuensi sangat tinggi ketika menjalani puasa sepuluh hari. Penurunan hormone terus berlangsung sampai tiga hari setelah diberikan asupan makanan ketika menjalani tahap ketiga. Pada hari keempat terjadi peningkatan kualitas hormon testosterone dibandingkan sewaktu sebelum puasa. Jadi puasa disamping mampu menurunkan hormon seks juga meningkatkan kualitas hormon. $^{42}$

Manfaat puasa yang lain juga berimplikasi bagi kesehatan jantung dapat diringkas ke dalam dua poin. Pertama, puasa meringankan kerja jantung. Dan kedua, puasa membersihkan darah. Keduanya membuat jantung dengan mudah mendapatkan pasokan darah bersih. Ketika yang masuk kedalam jantung hanya darah-darah yang bersih, maka kerja jantung pada hari-hari biasa setelah Ramadhan akan menjadi lancar.

Setiap menit jantung berdenyut sebanyak 80 kali. Ini sama dengan 115.200 (seratus lima belas ribu dua ratus) kali dalam 24 jam. Dihari pertama puasa, detak jantung berkurang hingga dibawah 60 kali per menit. Denyut jantung kembali meningkat hingga mencapai 60 kali per menit di sela-sela hari puasa. Maka, dalam sehari ketika puasa denyut jantung mengalami penurunan hingga mencapai 28.800 kali. Kondisi demikianlah yang dikatakan puasa memberi kesempatan jantung untuk istirahat, yakni dengan mengurangi pekerjaannya hingga tinggal seperempat saja.

Dengan diberi kesempatan untuk meringankan kerjanya selama berpuasa, jantung dapat bekerja secara maksimal dengan denyut yang lebih kuat di hari-hari biasanya. Selain memberi kesempatan istirahat kepada jantung, puasa juga memberikan hari libbur kepada lambung. ${ }^{43}$

\section{Perfektif Psikologis}

${ }^{42}$ Mutawalli Sya'rawi. 2006. Keistimewaan Puasa Menurut Syari'at dan Kedokteran. Tangerang. Qultummedia. Cet. Ke-1. Hlm. 64.

${ }^{43}$ Muhammad Ibrahim Salim. Op. cit. Hlm. 62. 
Daniel Goleman -seorang ahli dan peneliti tentang kecerdasan emosimengisahkan sebuah kisah menarik. Dalam sebuah penelitian, dikumpulkanlah anak-anak berusia empat tahun di taman kanak-kanak Stanford. Mereka diminta satu persatu masuk kedalam ruangan, dengan sepotong marshmallow yang diletakkan diatas meja dihadapan mereka, "kalian boleh memakan marshmallow jika mau. Terapi, kalau kalian memakannya setelah saya kembali lagi kesini, kalian berhak mendapat sepotong lagi."

Sekitar empat belas tahun kemudian, waktu anak-anak itu lulus sekolah lanjutan atas, anak-anak yang dulu langsung memakan marshmallow dibandingkan dengan anak-anak yang mampu menahan diri (sehingga mendapat dua potong marshmallow) itu memiliki ketahanan mental yang jauh berbeda antara satu dengan yang lain. Mereka yang tahan hingga menunggu hingga mendapatkan potongan marshmallow tambahan cenderung lebih tahan menghadapi stress, tidak mudsh tersinggung, dan tidak mudah berkelahi. Tidak demikian dengan anak-anak yang langsung melahapnya. Merekan memiliki kecenderungan kurang tahan uji dalam mengejar cita-cita mereka. Meski demikian, yeng lebih mengejutkan para peneliti adalah munculnya efek yang betul-betul tak terduga. Anak-anak yang mampu menahan diri dalam ujian marshmallow, dibandingkan dengan yang tidak tahan, memperoleh nilai rata-rata 210 lebih tinggi (dari nilai tertinggi 1.600) dalam ujian masuk perguruan tinggi.

Ketika anak-anak dari taman kanak-kanak Stanford itu tumbuh menjadi dewasa dan bekerja, perbedaan-perbedaan diantara mereka semakin mencolok. Dipenghujung usia duapuluhan, mereka yang lulus uji marshmallow ketika kanak-kanak tergolong anakyang cerdas, berminat tinggi, dan lebih mampu berkonsentrasi. Mereka lebih mampu mengembangkan hubungan yang tulus dan akrab dengan orang lain, lebuh handal, lebih bertanggung jawab, dan kendali dirinya lebih baik saat menghadapi frustasi. 


\section{Kearifan Syariat dan Hikmah Puasa}

Sebaliknya, mereka yang melahap marshmallow sewaktu berusia empat tahun, kemampuan kognitif mereka kurang dan kecakapan emosinya jauh lebih rendah dibandingkan kelompok yang tahan uji. Mereka lebih sering kesepian, kurang dapat diandalkan, lebih mudah kehilangan konsentrasi, dan tidak sabar menunda kepuasan dalam mengejar sasaran. Bila menghapadi stress, mereka hampir tidak mempunyai toleransi dan pengendalian diri. Mereka tidak luwes dalam menghadapi tekanan, bahkan sering mudah meledak dan hal tersebut menjadi kebiasaan mereka. ${ }^{44}$

Fenomena ini menunjukkan betapa pentingnya melatih pengendalian diri. Sebagai bagian dari bentuk kecerdasan emosional secara umum yang diyakini sementara orang sebagai penentu kesuksesan dan kebahagiaan. Sebagaimana kita tahu, puasa adalah arena melatih pengendalian diri yang sempurna. Dalam hal makan, yang menjadi kebutuhan penting bagi setiap orang, diberikan aturan yang cukup ketat, mulai pagi hingga sore hari. Dengan aturan yang begitu jelas, bisa dikatakan masyarakat muslim telah hidup dalam dunia yang penuh dengan aturan. Lebih-lebih ketika bulan Ramadhan. Dengan demikian, umat Islam telah melakukan pengendalian diri secara bersama-sama dibawah sebuat aturan yang mengatur. ${ }^{45}$

\section{Perfektif Sosial}

Dengan merasakan betapa menderitanya menahan lapar dan dahaga selama berpuasa, akan menumbuhkan rasa kasih sayang, solidaritas, dan kepedulian sosial terhadap nasib mereka yang hidup dibawah garis kemiskinan. Kelaparan dan kehausan hanya dirasakan selama satu bulan, padahal orang-orang yang hidup serba kekurangan merasakannya sepanjang tahun. Perasaan ini akan mendorong seseorang untuk bersedekah dan menghilangkan sikap individualisnya sehingga tercipta hubungan harmonis antara orang kaya dan miskin.

\footnotetext{
${ }^{44}$ Daniel Goleman. 2003. Kecerdasan Emosi untuk Mencapai Puncak Prestasi. Terjemahan Alex Tri Kantjono dari Working With Emotional Inteligence. Jakarta: Gramedia Pustaka Utama. Cet. Ke-5. Hlm.125-126.

${ }^{45}$ Musthofa As Siba'i. Op Cit. Hlm.51.
} 
Dengan merasakan tidak makan dan minum selama berpuasa, mereka yang dianugerahi kelebihan berupa jabatan, kekuatan, dan harta, akan menyadari bahwa sebenarnya tidak ada perbedaan antara dirinya dengan orang-orang lemah, fakir, dan miskin. Sebab, kapanpun Allah swt. Menghendaki anugerah berupa jabatan dan kekayaan dapat dicabut dari tangannya setiap saat. Mereka akan menjadi makhluk yang lemah, kecil, dan meminta-minta belas kasihan dari orang lain. ${ }^{46}$

\section{G. Penutup}

Syariat lebih khususnya ibadah, adalah sesuatu yang harus kita laksanakan dengan penuh ketundukkan dan kehambaan semata-mata karena allah swt, ada atau tidaknya manfaat-hikmah, tidak berpengaruh terhadap hukum suatu ibadah, bagaimanapun juga ibadah harus tetap dijalankan. Namun mempertanyakan dan berusaha mengetahui hikmah yang terkandung dalam syariat allah swt, bukanlah sesuatu yang bertentangan dengan keimanan dan keihklasan. Dalam alquran dan hadist sendiri ketika menjelaskan suatu syariat tak jarang juga menampilkan faedah dan hikmah-hikmahnya. Bahkan mengetahui syariat menjadi sangat penting jika karenanya penghayatan dan kekhusu'an pelaksanaan ibadah dapat dijalankan. Sekaligus semakin memantapkan dan menambah Iman kita kepada Allah yang Maha Arif an Mahabijak

Para ulama telah sepakat bahwa puasa adalah wajib dan merupakan salah satu pilar dari beberapa pilar islam yang lima, dalam tradisi keilmuan islam (Fiqh) puasa diartikan sebagai menahan dari keseluruhan sesuatu yang membatalakan puasa (makan, minum, bersenggama) mulai dari terbitnya fajar sampai terbenamnya matahari dengan niat dan syarat-syarat tertentu.

Walaupun puasa wajib Dalam ketentuannya tidak semua orang diwajibkan melakukan puasa, ada beberapa pengecualian bagi orang ketika dalam kondisi tertentu mendapatkan dispensasi (Rukhshoh) untuk tidak menjalankan ibadah puasa. Ada yang karena alasan menjaga kesehatan

\footnotetext{
${ }^{46 ،}$ Izzuddin bi Abdissalam. Op. Cit. Hlm. 16.
} 


\section{Kearifan Syariat dan Hikmah Puasa}

fisiknya baik kesehatannya sendiri seperti orang sakit, atau kesehatannya orang yang menjadi bebannya (wanita hamil dan menyusui), dan ada juga yang karena timbulnya Masyaqqah atau kesulitan dalam menjalankannya seperti wanita haid dan nifas serta orang yang melakukan perjalanan (Musafir).

Kajian tentang hikmah puasa, Seiring deengan berkembangnya Ilmu Pengetahuan akan selalu dinamis dan memunculkan Fakta-fakta baru. Fenomena ini disatu sisi merupakan sebuah anugrah karena menjadi bukti kebenaran islam. Yang mampu mengintegrasikan antara ajaran agama dengan penemuan iilmiah. Disisi lain ternyata hal demikian juga menimnulkan efek negative bagi orang-orang yang hidup di zaman sekarang yang mengedepankan logika serta argumentasi ilmiah dalam menilai sesuatu sehingga mengaburkan subtansi puasa sebagai sebuah ritual ibadah dan bentuk pengabdian kepada allah swt. Serta untuk mendapatkan faedah dan manfaat kesehatan atau lainnya. 


\section{Mufaizin}

\section{Daftar Pustaka}

Abdur Rahman Hasan Al Midani. 1987. Ash Shiyam wa Ramadhan fi As Sunnah wa Al Quran. Damaskus: Darul Qalam. Cet. $\mathrm{Ke}-1$.

Abu Al Hasan Ali bin Habib Al Mawardi Al Bashri. Tt. Adab Ad Dunya wa Ad Din. Surabaya: Al Haramain.

Abu Ja'far bin Jarir Ath Thabari. 2001. Jami' Al Bayan fi Ta'wil Al Quran. Kairo: Dar Hajr. Cet. Ke-1. Jilid 3.

Ahmad bin Hajar Al Asqalani. Tt. Fath Al Bari Syarh Al Bukhari. Beirut: Darul Ma'arif. Jilid 8.

Ahmad Syarifuddin. 2003. Puasa Menuju sehat Fisik dan Psikis. Jakarta: Gema Insasi Press. Cet. Ke-1.

Ali Ahmad Al Jurjawi. 1997. Hikmah At Tasyri wa Falsafatuhu. Beirut: Darul Fikr. Cet. Ke-4.

Ali As-Shabuny, 2004. Rawai'ul Bayan Fi Tafsiri Ayatil Ahkam, Beirut. Darulkutub al-ilmiyah. Hlm491.

Ats Tsa'labi. Al Kassyaf wa Al Bayan. CD Al Maktabah Asy Syamilah Al Ishdar Ats Tsani. Jilid 1.

Daniel Goleman. 2003. Kecerdasan Emosi untuk Mencapai Puncak Prestasi. Terjemahan Alex - - -

Fakhruddin Muhammad Ar Razi. Tt. Tafsir Al Kabir Al Masyhur bi Mafatih Al Ghalib. Beirut: Darul Fikr.

Hasan bin Ahmad Hammam. Terapi dengan ibadah. Terjemah oleh tim Aqwam Solo dari At Tadawi bi Al Istighfar bi Ash Shadaqah bi Ad Du'a bi Al Quran bi Ash Shalah bi Ash Shaum. 2008. Solo: Aqwam Media Profetika. Cet. Ke-1.

Izzuddin bin Abdissalam. 1992. Maqashid As Shaum. Beirut: Darul Kutub Ilmiyah. Cet. Ke-1.

Mahmud Nazhim An Nasimi. Tt. As Shiyam Baina Tthib Wal Islam. Masyurat Lajnah Ilmiyah Linniqabah Atthibba halb.

Muhammad Abdul Azhim Az Zarqani. 2003. Mahalil Al 'Irfan fi 'Ulum Al Quran. Bairut: Darul Kutub Al Ilmiyyah. Cet. Ke-1.

Muhammad Ibrahim Salim. Tt. At Tadawi bi Ash Shiyam wa Mazayuhu Al 'Azhimah fi Al Wiqayah wa Ash Shiyanah Ash 


\section{Kearifan Syariat dan Hikmah Puasa}

Shihhiyyah wa Al Mu'alajah Al Jismiyyah wa An Nafsiyyah. Kairo: Maktabah Ibnu Sina.

Musthafa As Siba'i. Ahkamus Shiyam Wa Falsafatuhu.Beirut Al-MaktabulIslami

Mutawalli Sya'rawi. 2006. Keistimewaan Puasa Menurut Syari'at dan Kedokteran. Tangerang. Qultummedia. Cet. Ke-1.

Sulaiman Al Jamal. Tt. Futuhat Al Wahhab bi Taudhih Syarh Minhaj Ath Thullab Al Ma'ruf bi Hasyiyah Al Jamal. Beirut: Darul Fikr. Jilid 2.

Sulaiman Rasyid, 2013. Fiqh Islam, Sinar Baru Algensindo Bandung,

Taqiyuddin Al hishny. 2005. Kifayatul Akhyar. Beirut Darul Kutub Ilmiyah.

Tri Kantjono dari Working With Emotional Inteligence. Jakarta: Gramedia Pustaka Utama. Cet. Ke-5.

Yusuf al hajj ahmad. 2003. Mausu'ah Al I'jaz Al I'lm Fil Qur'anil Karim Was Sunnah Al Muthaharah.Damaskus. maktabah ibnu hajar

Zakariya Anshori, Tt.Ghayatul Wushul. Surabaya. Al aharamain 